Інга Хмелевська

Південноукраїнський національний педагогічний

університет імені К. Д. Ушинського»

ORCID ID 0000-0001-9129-2173

DOI 10.24139/2312-5993/2019.07/304-316

\title{
СТРУКТУРА ІНТЕГРАЛЬНОÏ КОМПЕТЕНТНОСТІ МАЙБУТНІХ ВИКЛАДАЧІВ МИСТЕЦЬКИХ ДИСЦИПЛІН
}

У статті досліджено структуру інтегральної компетентності майбутніх викладачів мистецьких дисциплін, як мета-кваліфрікаційного конструкту, функція якого полягає в координації процесів актуалізації та формування компетентностей, відповідно до мети та завдань варіативно-творчого процесу мистецької освіти. У результаті аналізу наукової літератури визначено, що таку структуру складають мотиваційно-самокоригувальний, компетентнісно-адаптаційний, методичноперсоналізований, творчо-інтерпретаційний компоненти. Подальші дослідження передбачають визначення методологічних засад методики формування інтегральної компетентності майбутніх викладачів мистецьких дисциплін.

Ключові слова: інтегральна компетентність, майбутні викладачі мистецьких дисциплін, структурні компоненти, міждисциплінарність, інтерпретація, мистецько-творчий освітній процес, компетентності.

Постановка проблеми. Сучасні вимоги до компетентнісного рівня викладачів мистецької освіти зумовлені актуальними суспільними пріоритетами, що передбачають інтенсифікацію культурно-інтеграційних процесів. Забезпечення означеної потреби реалізується спрямованістю освітньої системи на підготовку конкурентоспроможних фахівців, які володіють відповідним комплексом фахових, полікультурних, кросмистецьких, методичних, особистісних, самоосвітніх тощо компетентностей. Ефективне функціонування означеного комплексу потребує інтегрального механізму, який координує процеси компетентнісної сфери фахівців, з огляду на специфічні особливості та актуальні завдання мистецької освіти. У нормативних документах, які стандартизують пріоритетні напрями розвитку вищої освіти на державному рівні визначається інтегральна компетентність, як така, що узагальнено характеризує кваліфікаційний рівень - «структурну одиницю Національної рамки кваліфікацій, що визначається певною сукупністю компетентностей (результатів навчання)» (Про затвердження Національної рамки кваліфікацій: Постанова Кабінету міністрів України № 1341, 2011). Розроблюючи концептуальні основи запровадження національної рамки кваліфікацій, В. Луговий (Луговий, 2014) уточнює функції IK, визначаючи їі в якості чинника, що забезпечує можливість фахівця діяти в «невизначених умовах» професійної діяльності. У контексті дослідження компетентнісної сфери майбутніх викладачів мистецьких 
дисциплін у якості невизначених умов розглядається специфіка мистецькоосвітнього процесу, яка характеризується творчим варіативним характером. У зв'язку з цим значущим чинником, що впливає на ефективність варіативнотворчого процесу мистецької освіти, $€$ сформованість інтегральної компетентності майбутніх викладачів мистецьких дисциплін. У попередніх дослідженнях було встановлено, що означена компетентність $\epsilon$ кваліфікаційним мета-конструктом, сутність якого визначається його функціональною роллю, що полягає в координації процесів формування та актуалізації компетентностей відповідно до вимог варіативно-творчого процесу мистецького навчання (Хмелевська, 2018). Проте визначення потребує структура інтегральної компетентності майбутніх викладачів мистецьких дисциплін.

Аналіз актуальних досліджень. Оскільки інтегральна компетентність (далі IK) майбутніх викладачів мистецьких дисциплін не стала предметом досліджень учених, з метою конкретизації структурних компонентів означеного феномену нами було вивчено наукові погляди дослідників щодо структури IК викладачів інших освітніх галузей.

Так О.Іваницький (Іваницький, 2017, с. 130), розглядаючи IK майбутнього вчителя фізики як «здатність розв'язувати складні спеціалізовані задачі та практичні проблеми в галузі середньої освіти...», конкретизує ії зміст через визначення загальних (таких, що охоплюють загальні знання і здатності) та предметних (таких, що відображають специфіку діяльності) компетентностей.

Подібних висновків доходить С. Толочко (Толочко, 2019, с. 23-24), досліджуючи IK педагогічного та науково-педагогічного персоналу для системи післядипломної педагогічної освіти. Учена доводить, що означений конструкт вважається таким, що має бінарну структуру, адже складається 3 двох груп компетентностей: загальних (володіючих універсальністю щодо різних предметних галузей) та професійних (таких, що «застосовуються в певній предметній галузі науки»).

М. Марусинець (Марусинець, 2018, с. 82) у якості компонента IK викладача закладу вищої освіти розглядає психолого-педагогічну компетентність як феномен, у якому інтегруються педагогічні та психологічні знання й професійні цілі.

Г. Резниченко (Резніченко, 2019, с. 154) здійснює аналіз основних функціональних складників інтегральної компетентності вчителя образотворчого мистецтва, виокремлюючи серед таких гностичний, конструктивно-плануючий, організаторський, комунікативно-навчальний компоненти та увиразнює значущість їх спрямованості на вирішення певних освітніх, виховних, творчо-розвивальних завдань.

Отже, досліджуючи IK, учені визначають у ї̈ структурі низку компетентностей, систематизуючи їх у певні професійно-кваліфікаційні 
комплекси, відповідно до функцій, які вони виконують у компетентнісній сфері фахівців.

Мета статті - визначити структурні компоненти інтегральної компетентності майбутніх викладачів мистецьких дисциплін як кваліфікаційного мета-конструкту, який виконує в їх компетентнісній сфері координувальну функцію, спрямовану на оптимізацію процесу професійної діяльності в невизначених умовах варіативно-творчого мистецько-освітнього процесу.

у дослідженні застосовано методи: аналізу наукової літератури, систематизації отриманої інформації, теоретичного моделювання.

Виклад основного матеріалу. Визначення компонентів інтегральної компетентності (далі IK) майбутніх викладачів мистецьких дисциплін вимагає уточнення принципів ії структурної організації. За твердженням М. Головань (Головань, 2011), компетентність у сфері освіти - «це інтегративне утворення особистості, що поєднує знання, уміння, навички, досвід і особистісні якості, які зумовлюють прагнення, готовність і здатність розв'язувати проблеми й завдання, що виникають у реальних життєвих ситуаціях, усвідомлюючи при цьому значущість предмета та результату діяльності» (Головань, 2011, с. 232). Проте, як було з'ясовано вище, у результаті аналізу наукової літератури, IK $€$ мета-утворенням, що охоплює та координує професійні, фахові, особистісні тощо компетентності вчителів. Усвідомлюючи, що IK $\epsilon$ цілісним конструктом, визначимо, що зміст структурних компонентів ІІ має включати структурні компоненти компетентностей, які вона в певний спосіб охоплює. У зв'язку з цим нами було вивчено та систематизовано розвідки науковців щодо складу компетентностей майбутніх фахівців мистецької освіти. Із цією метою насамперед було розглянуто обґрунтовані вченими різновиди компетенцій, які характеризуються певним ступенем інтегральності, адже комплексно забезпечують мистецько-освітній процес.

Серед таких визначена М. Михаськовою (Михаськова, 2007) фрахова компетентність майбутнього вчителя музики, яка, за твердженням ученої, складається з ціннісно-орієнтаційного (ціннісні орієнтації як «нормативно-регулятивні механізми оцінної діяльності»), когнітивного (музично-теоретичні, технологічні, методичні знання як «теоретична й методична основа ефективної діяльності вчителя музики»), практичнотворчого («сукупність музично-естетичного досвіду, музично-виконавських умінь, творчої самостійності») компонентів (Михаськова, 2007, с. 9).

Н. Цюлюпою (Цюлюпа, 2009) у складі методичної компетентності майбутніх учителів музики визначено когнітивно-інформаційний, операційно-регулятивний, емоційно-ціннісний та творчо-діяльнісний компоненти, що охоплюють «музичний кругозір, асоціативні зв'язки, оперативні знання та вміння, самостійність та креативність мислення у вирішенні музично-педагогічних завдань» (Цюлюпа, 2009, с. 16). 
У праці Н. Юдзіонок (Юдзіонок, 2011) серед компонентів професійної компетентності майбутнього вчителя музики в музично-інтерпретаційній діяльності розглянуто мотиваційно-ціннісний (інтерес та естетично-оцінне ставлення до інтерпретації), когнітивно-операційний (володіння навичками практичного втілення науково-педагогічних та музично-теоретичних, мистецтвознавчих знань у процесі інтерпретації), креативно-рефлексивний (розпізнання та осмислення «художньо-смислових елементів твору», генерація суб'єктивно-творчої інтерпретаційної концепції, уміння «коригувати власний психічний стан» у напрямі концентрації на творчому самовираженні у виконавському процесі) компоненти (Юдзіонок, 2011, с. 9-10).

Н. Мурована (Мурована, 2008) визначає у структурі профессійної компетентності вчителя музики низку компетенцій (ключових, регулятивних, комунікативних, операційних, інтелектуально-педагогічних), характеризуючи їх за принципом функціональності (Мурована, 2008, с. 9).

Натомість, функціональність інтегральної компетентності, як професійно-особистісного конструкту, що координує динамічні процеси компетентнісної сфери викладачів мистецьких дисциплін, визначається універсальністю застосування, отже охоплює як інтегративні, так і вузькоспрямовані компетентності, які забезпечують певні ланки процесу мистецької освіти. Так, ученими вивчено комунікативну компетентність учителя музики (Є. Проворова, 2008); професійну компетентність майбутнього вчителя музики щодо організації та проведення спільної навчальної діяльності учнів (Т. Борисенко, 2005); концертмейстерську компетентність (Т. Карпенко, 2010); оркестрово-методичну компетентність учителя музики (Т. Пляченко, 2011); компетентність хорового диригента (Н.Селезнева, 2004); розглянуто компетенції як критерії сформованості професійного менталітету вокалістів (О. Оганезова-Григоренко, 2009).

у педагогічній галузі наукових досліджень хореографічні компетентності вивчено менш ґрунтовно, проте проблематику формування певних компетентностей майбутніх хореографів розглянуто з різних ракурсів у роботах науковців (Т.Благова, Ван Юаньсінь, І. Спінул, В. Черкасов). Особливу увагу в контексті дослідження привертають праці, у яких науковцями зроблено структурний аналіз компетентностей майбутніх викладачів хореографії. Зокрема, слушними є розвідки О. Авраменко, який провів дослідження інформаційно-комунікаційної компетентності майбутніх хореографів та визначив у їі структурі ціннісно-мотиваційний, змістовий, діяльнісний, рефлексійний компоненти (Авраменко, 2018, с. 55-56). С. Твердохлібом як актуальну розглянуто інтерпретаційну компетентність учителя хореографії, у структурі якої дослідник розглядає когнітивний компонент, що охоплює «загальнонаукові, психолого-педагогічні, професійні, методичні» знання та «балетмейстерські, художньо-комунікативні, хореографічнотехнічні» вміння та навички майбутніх хореографів (Твердохліб, 2018, с. 220). 
у дослідженні Т. Медвідь (Медвідь, 2018, с. 236-237) зроблено комплексний аналіз компетентностей майбутніх хореографів. Учена диференційовано систематизує знання, уміння й навички за їх належністю до «базових» та «спеціальних» компетентностей хореографа за принципом актуальності їх застосування безпосередньо в пластично-хореографічному процесі. Наприклад, інтерпретаційні вміння в наведеному переліку компетентностей хореографа охоплено в межах як мистецтвознавчої, так $\mathrm{i}$ художньо-сценічної, компетентностей. Наведене дозволяє припустити наступне: за думкою ученої, задля успішної фахової діяльності (зокрема, постановчого, педагогічного, художньо-сценічного ї̈ видів) хореографу достатньо базових мистецтвознавчих знань та вмінь хореографічної інтерпретації музичного твору (базової компетентності), проте її пластичний складник, який відповідає за вибір тих чи інших хореографічних елементів та хореографічно-виконавську техніку вимагає глибинних спеціальних знань, умінь та навичок (спеціальної компетентності). Означене $\epsilon$ цілком виправданим підходом, спрямованим на забезпечення високого рівня хореографічно-виконавської підготовки. Натомість, очевидним $\epsilon$ те, що інтеграція змісту мистецтвознавчої та хореографічної компетенцій у цілісний компетентнісний конструкт сприятиме збагаченню художнього складника інтерпретаційної концепції, як педагогічної, так і виконавської. 3 цього приводу в докторському дослідженні Г. Ніколаї зазначається, що, не зважаючи на автономність мистецьких фахових компетентностей, результати наукових досліджень інтеграційних процесів у мистецтві збагачують теорію i практику мистецької освіти, адже розкривають «зв'язки між автономними видами художньої діяльності» (Ніколаї, 2008, с. 27).

В означеному контексті особливий інтерес представляють дослідження, у яких учені визначають інтегральні міждисциплінарні структурні компоненти компетентностей майбутніх учителів мистецьких дисциплін. Так, у дисертації Лю Цяньцянь (Лю Цяньцянь, 2010) визначено компоненти художньої компетентності, що $€$ спільними для студентівмузикантів і хореографів, серед яких художньо-комунікативний (художньомовна, термінологічна грамотність), методико-педагогічний (педагогічні, методичні, самоорганізаційні компетентності), синкретично-аналітичний (мистецтвознавчі, аналітично-оцінні знання та вміння), виконавськоінтерпретаційний (виконавські, художньо-інтерпретаційні компетентності, рефлексія) компоненти (Лю Цяньцянь, 2010, с. 9).

У дисертації Л. Степанової (Степанова, 2018) у структурі художньогерменевтичної компетентності магістрів музичного мистецтва та хореографії конкретизовано художньо-перцептивний (цілісне емоційно-чуттєве сприйняття «художнього смислу твору»), семіотично-когнітивний (розуміння форми, специфіки певної мистецької мови, контексту), творчо-експлікаційний (педагогічна вербалізація художнього змісту твору), досвідно-педагогічний 
(накопичення художньо-герменевтичного досвіду та його актуалізація в педагогічному процесі) компоненти (Степанова, 2018, с. 9).

у праці Чжан Їна (Чжан Їн, 2017) розглядаються компоненти етнокультурної компетентності майбутніх викладачів музики та хореографії, а саме: мотиваційний (умотивованість оволодівати етнокультурною компетенцією, прагнення професійного розвитку), когнітивний (знання щодо організації педагогічної діяльності на засадах інтеріоризації етнокультурних традицій та міжнаціональної взаємодії), діяльнісний (уміння та навички «вести міжкультурний діалог та організовувати міжетнічну взаємодію», здійснювати «адекватну особистісну та професійну самооцінку») компоненти (Чжан Їн, 2017, с. 310).

Як бачимо, компетентності, обґрунтовані науковцями, спрямовані на забезпечення мистецько-освітнього процесу, концептуальною домінантою якого $€$ інтерпретація художніх творів. Інтерпретація слугує сполучною ланкою, що зумовлює інтегральність процесу актуалізації компетентностей викладачів музики та хореографії. Освітньо-виховна результативність означеного процесу, як видно з аналізу поглядів учених, забезпечується сформованістю певних здатностей, умінь, навичок, якостей тощо. Серед таких:

- мотивація, відповідні ціннісні орієнтації, самоврядувальні компетентності тощо (відповідно до розвідок науковців, найчастіше охоплюються мотиваційно-ціннісним компонентом);

- знання, уміння, навички, фахові та професійні компетентності (охоплюються когнітивним, або когнітивноінформаційним/операційним/імперативним тощо компонентом);

- емоційні, рефлексійні, особистісно-вольові, емпатійні, самооцінні тощо здатності (охоплюються рефлексійним компонентом);

- інтерпретаційно-виконавські, інтерпретаційно-педагогічні, психолого-педагогічні комунікативні, методично-організаційні тощо вміння (охоплюються діяльнісним, практично-творчим, творчо-діяльнісним, операційно-творчим компонентами).

Натомість структура IK, як кваліфікаційного мета-конструкту, який координує процеси формування та актуалізації компетентностей, не обмежується наведеними компонентами, проте містить складники, які забезпечують перебіг даного процесу. 3 метою визначення таких складників ми звернулися до «карти інтегральної індексації компетентнісної сфери майбутніх викладачів мистецьких дисциплін», розробленої в попередньому дослідженні на основі «інтегральної операційної системи (IOS)» К. Уїлбера (Wilber, 2005). Нагадаємо, що, за К. Уїлбером, інтегральна індексація передбачає виокремлення та систематизацію складників досліджуваного феномену за концептуальними квадрантами, кожен із яких являє собою площину дослідження з позицій: «я» (самоаналіз), «ми» (взаємодія задля досягнення певної мети), «ти» 
(відтворення та рефлексія здійсненого впливу), «вони» (осягнення віддалених явищ, артефактів культури тощо) (Wilber, 2005, с. 23-25).

У результаті інтегральної індексації компетентнісної сфери майбутніх викладачів мистецьких дисциплін нами було визначено, що інтегральна компетентність $\epsilon$ синергетичним конструктом, який реалізує координувальну функцію у вищезгаданих проекціях таким чином:

- «я»-проекція: самоаналіз власного компетентнісного рівню та визначення концепції його вдосконалення;

- «ми»-проекція: коригування процесів формування та актуалізації компетентностей «з метою синхронізації педагогічного впливу з боку різних дисциплін у межах процесу мистецької освіти (у тому числі компетентностей організації міждисциплінарного навчання)»;

- «ти»-проекція: коригування динаміки процесів компетентнісної сфери з огляду на потреби та особливості суб'єктів мистецької освіти (у тому числі застосування персоналізованих та індивідуалізованих методів навчання);

- «вони»-проекція: актуалізація та формування компетентностей актуалізації освітньої мистецько-культурологічної інформації в процесі виконавської та педагогічної інтерпретації, організації процесу художньопедагогічної комунікації тощо (Хмелевська, 2018, с. 111).

3 метою визначення структури IK майбутніх викладачів мистецьких дисциплін, зміст компонентів компетентностей, конкретизованих науковцями, було розглянуто в контексті вищенаведених проекцій. Так, погляд у площині «я»-проекції, пов'язаної із самокоригуванням власної компетентнісної сфери, ініціював привернення уваги до змісту мотиваційного компоненту. Зазначимо, що в сучасних психологічних дослідженнях, як потужні мотиваційні чинники розглядаються саморегуляція та самоаналіз. Зокрема, в результаті експериментального дослідження К. Меррік (Merrick, 2012) було доведено, що процес набуття навичок під час навчання здійснюється більш ефективно за умов актуалізації інтренсивної мотивації та самоврядувальних процесів. За спостереженням ученої, респонденти, які самостійно визначали навчальні цілі та, на основі цього, вирішували, які навички потрібно розвивати, активувати чи видаляти, ефективніше та міцніше засвоювали більш складну інформацію. Отже, мотивація розглядається як чинник, що спонукає майбутніх викладачів мистецьких дисциплін прагнути набуття певних професійних, особистісних, фахових компетентностей. У зв'язку з цим, визначаємо, що інтегральну функцію в цьому процесі відіграє самоаналіз компетентнісної сфери в інтегральній «я»-проекції, який відтворюється з метою постановки кваліфікаційних цілей та визначення шляхів їх досягнення. На цій основі виокремлюємо мотиваційносамокоригувальний компонент ІК, та його елементи, як-от: 
- усвідомлення потреб актуалізації певних компетентностей з метою вирішення завдань мистецько-освітнього процесу;

- умотивованість формування компетентностей задля досягнення самостійно визначених освітніх цілей.

Вивчення динаміки компетентнісних процесів у площині «ми»-проекції, пов'язаної із синхронізацією освітньої інформації в міждисциплінарному контексті, зумовило актуалізацію проблематики синкретичності мистецькоосвітнього процесу. У дослідженні Л. Іваницької та співавторів (Ivanitskaya et al., 2002) зазначається, що мистецьке навчання має бути інтеграційним та міждисциплінарним апріорі, адже його центральною проблемою є художній твір, який, будучи об'єктом культури, інтегрує в собі множину особистісних, соціальних, крос-мистецьких контекстів. Їх виявлення у процесі інтерпретації, за умов актуалізації міжпредметних зв'язків, розширює сферу наявних знань та формує здатності глибинного розуміння явищ життя через пізнання мистецтва. Таким чином, за визначенням науковців, інтеграційний та міждисциплінарний характер навчання мистецтву сприяє розвиткові епістомологічних умінь, здатностей до критичного мислення та метакогнітивних навичок (Ivanitskaya et al., 2002, с. 103). У зв'язку з цим визначаємо, що інтегральна «ми»-проекція пов'язана з когнітивним компонентом компетентностей. Виокремлення відповідного компоненту ІК актуалізує проблему адаптованості знаннєво-когнітивного складника компетентностей до виконання завдань мистецько-освітнього процесу, невизначеність умов якого зумовлюється низкою чинників. Серед таких слід згадати індивідуальні вікові, особистісні, перцептивні, компетентнісні особливості його суб'єктів, варіативно-творчий характер художньої комунікації, синкретичність мистецьких творів тощо. Отже, координаційна функція IK реалізується у площині когнітивного компоненту через процес адаптації змісту компетентностей (знань, умінь, навичок тощо) з метою вирішення певних освітніх завдань. 3 огляду на зазначене, виокремлюємо компетентнісноадаптаційний компонент, елементами якого було визначено:

- актуалізацію компетентностей з метою синхронізації знань у цілісний міжпредметний мистецько-інформаційний комплекс;

- формування й актуалізацію компетентностей адаптації мистецькоосвітньої інформацій з огляду на специфіку освітнього процесу та індивідуальні особливості його суб'єктів.

У ході дослідження структури IK у площині «ти»-проекції, пов'язаної із процесами індивідуалізації педагогічних підходів та застосуванням персоналізованих методів навчання, було актуалізовано проблематику пізнання іншого у процесі міжособистісної комунікації через рефлексію. Означене питання слушно розглянуто у праці Г. Кельхтерманса (Kelchtermans, 2009), який доводить, що «за допомогою рефлексивного аналізу вчителі набувають знань та навичок, які сприяють підвищенню ефективності 
навчання» (Kelchtermans, 2009, с. 267). За визначенням ученого, рефлексія функціонує через активацію трьох основних психологічно-особистісних механізмів: самооцінка з погляду моральності педагогічної дії, увага до емоційного складника педагогічної комунікації, «концепція віддзеркалення» суб'єкта освітнього процесу з метою глибинного пізнання його особистості та індивідуальних потреб (Kelchtermans, 2009, с. 268-269). Отже, реалізація коригувальної функції IK у площині «ти»-проекції спрямована на оптимізацію процесу добору персоналізованих методів навчання та педагогічної комунікації, на основі чого було визначено методично-персоналізований компонент IK із елементами:

- формування й актуалізація компетентностей осягнення індивідуальних особистісно-емоційних та психологічних особливостей суб'єктів освітнього процесу шляхом рефлексії;

- формування та координація компетентностей добору та проектування персоналізованих методів навчання.

Визначення структури IK шляхом актуалізації «вони»-проекції, пов'язаної 3 інтерпретацією художніх творів та організацією художньопедагогічної комунікації, зумовило привернення уваги діяльнісному компоненту компетентностей майбутніх викладачів мистецьких дисциплін. В означеному контексті специфіка мистецько-освітнього процесу зумовлює актуалізацію творчого складника, що підтверджується дослідженнями науковців. Зокрема, у роботі Л. Лавандер (Lavender, 2006), присвяченій проблематиці навчання хореографії, увиразнюється значущість творчого спрямування хореографічно-інтерпретаційного процесу. Учений доводить, спираючись на власний досвід та наукові дослідження, що творча спрямованість хореографічно-мистецького освітнього процесу сприяє формуванню вмінь генерувати креативні ідеї, які мотивують та спрямовують освітній процес, діагностувати та вирішувати мистецько-освітні завдання, усвідомлювати культурологічний та духовний контексти мистецтва (Lavender, 2006, с. 12). Отже, діяльнісний компонент, що $\epsilon$ пов'язаним із інтерпретаційним процесом, може відтворюватися як на репродуктивному, так і на творчому рівнях. Оскільки другий варіант визнається таким, що більш ефективно сприяє вирішенню виховних та розвивальних завдань мистецької освіти, функція IK убачається в коригуванні динаміки процесів компетентнісної сфери в напрямі набуття та актуалізації творчих компетентностей. На основі наведеного виокремлюємо творчоінтерпретаційний компонент, елементами якого визначаються:

- формування й актуалізація творчих виконавських та педагогічних інтерпретаційних компетентностей;

- формування й актуалізація творчо-діяльнісних організаційних та методичних компетентностей. 
Висновки та перспективи подальших наукових розвідок. У дослідженні було вивчено структуру інтегральної компетентності як кваліфікаційного мета-конструкту, який виконує функцію коригування процесів формування та актуалізації компетентностей майбутніх викладачів мистецьких дисциплін відповідно до вимог та завдань варіативно-творчого процесу мистецької освіти. У результаті аналізу літературних джерел, шляхом застосування методів аналізу, систематизації отриманої інформації, теоретичного моделювання, було визначено чотири структурні компоненти означеного феномену, як-от: мотиваційно-самокоригувальний, компетентнісно-адаптаційний, методично-персоналізований, творчоінтерпретаційний. Подальші наукові розвідки передбачають визначення методологічних засад та елементів методики формування інтегральної компетентності майбутніх викладачів мистецьких дисциплін.

\section{ЛITEPATУРА}

Авраменко, О. В. (2018). Формування інформаційно-комунікаційної компетентності майбутніх хореографів: Констатувальний етап. Педагогіка формування творчої особистості у вищій і загальноосвітній школах, 58-59, 52-60 (Avramenko, 0. V. (2018). Formation of information and communication competence of future choreographers: ascertaining stage. Pedagogy of formation of creative personality in higher and secondary schools, 58-59, 52-60).

Головань, М. С. (2011). Компетенція та компетентність: Порівняльний аналіз понять. Педагогічні науки: Теорія, історія, інноваційні технології, 8 (18), 224-234 (Holovan, M. S. (2011). Competency and competence: Comparative analysis of concepts. Pedagogical sciences: theory, history, innovative technologies, 8 (18), 224-234).

Іваницький, О.І. (2017). Формування інтегральної компетентності майбутнього вчителя фізики на засадах акмеологічного, контекстного та компетентністного підходів. Збірник наукових праць Кам'янець-Подільського національного університету імені Івана Огієнка, 23, 129-132 (Ivanytskyi, 0. І. (2017). Formation of the integral competence of the future physics teacher on the basis of acmeological, contextual and competence approaches. Proceedings of Kamianets-Podilskyi Ivan Ogiyenko National University, 23, 129-132).

Луговий, В. І. (2014). Європейські кваліфрікаційні метарамки: Запровадження Національної рамки кваліфікацій в контексті нового Закону України «Про вищу освіту». Матеріали Національної команди експертів проекту ЄС «НЕО в Україні». Режим доступу: http://bit.do/erasmusplus-org-ua (Luhovyi, V. I. (2014). European Qualifications Framework: Introducing the National Qualifications Framework in the context of the new Law on Higher Education of Ukraine. Materials of the National Team of Experts of the EU NEO Ukraine Project. Retrieved from: http:// bit.do/erasmusplus-org-ua).

Лю Цяньцянь. (2010). Формування художньої компетентності майбутніх учителів музики та хореографії в педагогічних університетах України і Китаю. (автореф. дис. ... канд. пед. наук: 13.00.02). Київ (Liu Qianqiang. (2010). Formation of artistic competence of future teachers of music and choreography in pedagogical universities of Ukraine and China (PhD thesis abstract). Kyiv).

Марусинець, М. (2018). Формування інтегральної психолого-педагогічної компетентності викладача закладу вищої освіти. Освітній простір України(14), 
81-88 (Marusynets, M. (2018). Formation of integral psychological-pedagogical competence of a teacher of the higher education institution. Educational Space of Ukraine (14), 81-88).

Медвідь, Т. А. (2018). Компетентнісні засади професійної підготовки майбутніх хореографів у класичному університеті. Вісник Національної академії керівних кадрів культури і мистецтв, 2, 234-238 (Medvid, T. А. (2018). Competence principles of professional training of future choreographers in classical university. Bulletin of the National Academy of Art and Culture Leadership, 2, 234-238).

Михаськова, М. (2007). Формування фахової компетентності майбутнього вчителя музики. (автореф. дис. ... канд. пед. наук: 13.00.02). Київ (M ykhaskova, M. (2007). Formation of professional competence of the future music teacher (PhD thesis abstract). Kyiv).

Мурована, Н. М. (2008). Педагогічне керівництво розвитком профресійної компетентності вчителів музики у післядипломній освіті. (автореф. дис. ... канд. пед. наук: 13.00.06). Київ (M urovana, N. М. (2008). Pedagogical guidance for the development of professional competence of music teachers in postgraduate education (PhD thesis abstract). Kyiv).

Ніколаї, Г. Ю. (2008). Розвиток музично-педагогічної освіти в Польщі (XX століття) (автореф. дис. ... д-ра. пед. наук: 13.00.01). Київ. (Nikolai, H. Yu. (2008). Development of Musical Pedagogical Education in Poland (20th century) (DSc thesis abstract). Kyiv).

Про затвердження Національної рамки кваліфікацій: Постанова Кабінету міністрів України № 1341 §. (2011). Режим доступу:

http://search.ligazakon.ua/I doc2.nsf/link1/KP111341.html (On approval of the National Qualifications Framework: Resolution of the Cabinet of M inisters of Ukraine No. $1341 \quad$ §. $\quad$ (2011). $\quad$ Retrieved from: http://search.ligazakon.ua// doc2.nsf/link1/KP111341.html).

Резніченко, Г. (2019). Розвиток інтегральної компетентності учителя образотворчого мистецтва в системі післядипломної освіти. Молодь і ринок, 2, 151-156 (Reznichenko, H. (2019). Development of integral competence of the teacher of fine arts in the system of postgraduate education. Youth and Market, 2, 151-156).

Степанова, Л. В. (2018). Методика формування художньо-герменевтичної компетентності магістрів музичного мистецтва та хореографії (автореф. дис. ... канд. пед. наук: 13.00.02). Суми (Stepanova, L. V. (2018). Methods of formation of artistic-hermeneutic competence of masters of musical art and choreography (PhD thesis abstract). Sumy).

Твердохліб, С. С. (2018). Когнітивний компонент у контексті формування інтерпретаційної компетентності майбутніх учителів хореографії. Наукові записки Центральноукраїнського державного педагогічного університету імені Володимира Винниченка. Серія: Педагогічні науки, 167, 216-221 (Tverdokhlib, S. S. (2018). A cognitive component in the context of forming the interpretive competence of future choreography teachers. Scientific notes of Volodymyr Vinnychenko Central State Pedagogical University. Series: Pedagogical Sciences, 167 , 216-221).

Толочко, С. В. (2019). Інтегральна компетентність педагогічного та науковопедагогічного персоналу для системи післядипломної педагогічної освіти (Tolochko, S. V. (2019). Integral competence of pedagogical and scientificpedagogical staff for the system of postgraduate pedagogical education). ScienceRise: Pedagogical Education, 1 (28), 22-29. 
Хмелевська, І. О. (2018). Інтегральна компетентність майбутніх викладачів мистецьких дисциплін. Актуальні питання мистецької освіти та виховання, 2(12), 105115. Режим доступу: http://nbuv.gov.ua/UJRN/apmov_2018_2_12

Цюлюпа, Н. Л. (2009). Педагогічні умови формування методичної компетентності майбутнього вчителя музики в процесі інструментальної підготовки (автореф. дис. ... канд. пед. наук: 13.00.02). київ (Tsiuliupa, N. L. (2009). Pedagogical conditions of formation of methodological competence of the future music teacher in the process of instrumental preparation (PhD thesis abstract). Kyiv).

Чжан Їн. (2017). Модель формування етнокультурної компетентності майбутніх учителів музики і хореографії з КНР у вищих педагогічних навчальних закладах України. Проблеми підготовки сучасного вчителя, 16, 306-313 (Zhang Yong (2017). M odel of formation of ethno-cultural competence of future teachers of music and choreography from the People's Republic of China in higher pedagogical education institutions of Ukraine. Contemporary Teacher Training Problems, 16, 306-313).

Юдзіонок, Н.М.(2011). Формування професійної компетентності майбутнього вчителя у музично-інтерпретаційній діяльності (автореф. дис. ... канд. пед. наук: 13.00.04). Одеса (Yudzionok, N. М. (2011). Formation of professional competence of the future teacher in music-interpretation activity (PhD thesis abstract). Odesa).

Ivanitskaya, L., Clark, D., M ontgomery, G., \& Primeau, R. (2002). Interdisciplinary learning: Process and outcomes. Innovative higher education, 95-111. Retrieved from: https://www.researchgate.net/publication/225958578

Kelchtermans, G. (2009). Who I am in how I teach is the message: Self-understanding, vulnerability and reflection. Teachers and Teaching: theory and practice, 15 (2), 257272. Retrieved from: https://doi.org/10.1080/13540600902875332

Lavender, L. (2006). Creative process mentoring: Teaching the "making" in dance-making. Journal of Dance Education, 6 (1), 6-13. Retrieved from: https://doi.org/10.1080/15290824.2006.10387306

Merrick, K. E. (2012). Intrinsic motivation and introspection in reinforcement learning. IEEE Transactions on Autonomous Mental Development, 4 (4), 315-329. Retrieved from: https:// ieeexplore.ieee.org/abstract/document/6239563.

Wilber, K. (2005). Introduction to Integral Theory and Practice: IOS Basic and the AQAL Map. Journal of Integral Theory and Practice, 1 (1), 2-38. Retrieved from: http://rucore.org.za/wp-content/uploads/2011/11/Ken-Wilber_Introduction-toIntegral.pdf

\section{PEЗЮME}

Хмелевская Инга. Структура интегральной компетентности будущих преподавателей художественных дисциплин.

В статье исследована структура интегральной компетентности будущих преподавателей художественных дисциплин, как мета-квалифрикационный конструкт, функция которого заключается в координации процессов актуализации и формирования компетентностей в соответствии с целями и задачами вариативно-творческого процесса художественного образования. В результате анализа научной литературы определено, что такую структуру составляют мотивационно-самокорректирующий, компетентностно-адаптационный, методически персонализированный, творчески-интерпретационный компоненты. Дальнейшие исследования предполагают определение методологических основ методики формирования интегральной компетентности будущих преподавателей художественных дисциплин. 
Ключевые слова: интегральная компетентность, будущие преподаватели художественных дисциплин, структурные компоненты, междисциплинарность, интерпретация, художественно-творческий образовательный процесс, компетентности.

\section{SUM M ARY} disciplines.

Khmelevska Inga. The structure of integral competence of future teachers of art

The article explores the structure of integral competence of future teachers of art disciplines as a meta-qualification construct whose function is to coordinate the processes of updating and forming competences in accordance with the goals and objectives of the variative-creative process of artistic education. Conducted analysis of scientific literature with subsequent systematization of the information obtained made it possible to establish that the competences of future teachers of art disciplines are called upon to ensure the artisticeducational process, the conceptual dominant of which is interpretation of works of art. It is determined that interpretation (performing and pedagogical) presupposes the existence of a formed set of competences that provides the opportunity to comprehend the meanings of a work of art at an interdisciplinary level, as well as the capability, intention and ability to organize the artistic-educational process taking into account individual age, perceptual psychological, personal, competence and other features of its subjects. The mentioned qualities and skills are traditionally studied by scientists in the framework of the motivational, cognitive, reflexive and activity components of the competences. However, the structure of integral competence, as a meta-qualification construct, in addition to the content of the mentioned components, includes components that provide coordination of the dynamic processes of formation and updating of the competences of future teachers of art disciplines. Such components were identified in the process of the study, by indexing the competence sphere of the mentioned specialists using the "Integrated Operating System (IOS)" by K. Wilber. As a result, it is determined that the integral competence of future art teachers is a synergetic construct that implements the coordinating function in four projections of the quadrants of the integral operating system of $\mathrm{K}$. Wilber, and consists of motivational-self-correcting, competence-adaptive, methodological-personalized, creativeinterpretative components. Further research involves determination of the methodological foundations of the methodology for the formation of the integral competence of future teachers of art disciplines.

Key words: integral competence, future teachers of art disciplines, structural components, interdisciplinarity, interpretation, artistic-creative educational process, competences. 